\title{
Neonatal Adaptation: Cardiac Adrenergic Effector Mechanisms after Birth in Newborn Sheep
}

\author{
DAVID M. HABIB, JAMES F. PADBURY, ALMA M. MARTINEZ, BARBARA A. CHAPPELL, \\ SIANG L. THIO, AND ELIZABETH E. BURNELL \\ Perinatal Research Laboratories, Harbor-UCLA Medical Center, UCLA School of Medicine, \\ Torrance, California 90509
}

\begin{abstract}
At birth, there is a marked increase in circulating plasma catecholamine concentrations. This increase is critical to many of the physiologic adjustments to postnatal life. Because the levels observed are higher than those seen in most other physiologic conditions in adults, previous investigators have suggested that the newborn is less sensitive to adrenergic stimulation or that desensitization to adrenergic stimulation occurs rapidly. To investigate this question, we designed experiments to measure myocardial $\beta$-adrenergic receptor density and sensitivity before and after exposure to the catecholamine surge at birth in term newborn sheep. We also measured the status of sympathetic innervation, reflected by myocardial norepinephrine content. At birth, plasma catecholamines increased 4- to 6-fold with associated increases in heart rate, blood pressure, and cardiac output. Myocardial $\beta$-adrenergic receptor at birth (135 fmol/mg protein) did not change significantly by $6 \mathrm{~h}$ of life (157 fmol/mg protein). Myocardial adenyl cyclase activity, reflecting receptor sensitivity, and myocardial sympathetic innervation also did not change. These results suggest that, despite exposure to sustained adrenergic stimulation, myocardial adrenergic effector mechanisms do not change in the newborn sheep at birth. (Pediatr Res 29: 98-103, 1991)
\end{abstract}

Abbreviations

BAR, $\beta$-adrenergic receptor

GTP, guanosine triphosphate

$\mathbf{E C}_{\text {so }}$, half maximal concentration

Bmax, maximum binding capacity

${ }^{3} \mathrm{H}$-DHA, tritiated dehydroalprenolol

$\mathrm{PaO}_{2}$, partial pressure of arterial oxygen

Classical receptor theory holds that prolonged receptor occupancy leads to decreased responsiveness. This phenomenon, variously referred to as tachyphylaxis or down-regulation, has been demonstrated to occur in response to endogenous hormones, neurotransmitters, growth factors, or exogenous agents with specific affinity for a single class of receptors (1-3). Alterations in receptor number alone are referred to as homologous regulation and changes in sensitivity due to alteration in receptor coupling to second messenger systems are referred to as heterologous regulation $(2,3)$. This process has been demonstrated to

Received July 28, 1990; accepted August 27, 1990

Correspondence and reprint requests: Dr. David M. Habib, University of South Carolina, Department of Pediatrics, Children's Hospital, Division of Critical Care, 171 Ashley Avenue, Charleston, SC 29425-3305.

Supported in part by a grant from the USPHS (HD-18014) and an Investigative Group Fellowship Award from the American Heart Association. Los Angeles Affiliate. occur both in vivo and in vitro in response to both endogenous and exogenous receptor ligands (4-21).

At birth, there is a marked increase in sympathoadrenal activity reflected by changes in circulating catecholamine concentrations. Plasma norepinephrine rises 5- to 10-fold and plasma epinephrine 10- to 20 -fold over the first several hours of life (2226). We have previously demonstrated that the majority of circulating norepinephrine arises from increased postganglionic sympathetic nerve activity (24), whereas the increase in plasma epinephrine is derived almost solely from adrenal medullary secretion (25). These changes are critical to successful postnatal physiologic adaptation and survival (25). It is unclear, however, to what extent these changes in circulating catecholamines affect adrenergic receptor mechanisms after birth. Because circulating catecholamine levels in the early newborn period are higher than those observed in most other physiologic conditions in adults (22), previous investigators have suggested that the newborn is less sensitive to adrenergic stimulation or that desensitization to adrenergic stimulation occurs rapidly (26). To examine this question, we designed experiments in newborn fetal sheep to measure cardiac BAR and catecholamine-stimulated adenyl cyclase activity in newborn sheep after exposure to the surge in catecholamines at birth.

\section{MATERIALS AND METHODS}

Sixteen Western mixed breed fetuses from time-dated singleton, twin, or triplet pregnancies were operated on at $139 \mathrm{~d}$ (term is $150 \mathrm{~d}$ ). The details of delivery and postnatal stabilization were identical to previous reports (25). After overnight fast, the ewes were premedicated with ketamine $(750 \mathrm{mg})$ and atropine $(1.2$ $\mathrm{mg}$ ). Maternal jugular venous catheterization was performed and anesthesia was maintained by continuous infusion of ketamine at $5 \mathrm{mg} / \mathrm{min}$ during surgery. Fetuses were randomly assigned to death immediately at birth or after $6 \mathrm{~h}$ of ventilation. The fetal head and neck were delivered through the uterine incision and fetal breathing was prevented by immediately placing a warm towel over the head and around the mouth. After local anesthetic infiltration, a tracheotomy was performed through a midline longitudinal neck incision and an appropriately sized endotracheal tube was secured in place. A 5.0 F catheter was inserted via the right common carotid artery into the left ventricle under direct oscilloscopic pressure monitoring. Time zero animals were delivered and killed immediately with a lethal dose of sodium pentathol. All 6-h animals were delivered onto the maternal abdomen, covered with a heating pad and warm towels, and allowed to stabilize for 10 to $15 \mathrm{~min}$. Arterial blood for blood gases and plasma catecholamines was obtained at -10 and 0 min (time zero is denoted at the time of umbilical cord clamping). Immediately after cord cutting, the animals were transferred to radiant warmers and placed on time-cycled, pressure-limited infant ventilators. All animals were given pancuronium $(0.1 \mathrm{mg} /$ $\mathrm{kg}$ ) to provide continuous muscle paralysis and ventilatory set- 
tings were adjusted to maintain blood $\mathrm{pH}$ and $\mathrm{PaO}_{2}$ between 7.35 and 7.50 and 100 to $150 \mathrm{~mm} \mathrm{Hg}$ (13 to $20 \mathrm{kPa}$ ), respectively. A 3.5 F umbilical artery catheter was inserted for blood sampling, hemodynamic monitoring, and administration of $10 \%$ dextrose at an infusion rate of $100 \mathrm{~mL} / \mathrm{kg} / 24 \mathrm{~h}$. Rectal body temperature was maintained at $39^{\circ} \mathrm{C}$ using a radiant warmer and supplemental heat lamps. After delivery, ventilation, and stabilization, animals underwent placement of a $5.0 \mathrm{~F}$ thermodilution pulmonary artery catheter via the right internal jugular vein. Cardiac output was determined from a $2.0-\mathrm{mL}$ normal saline injection kept at $19-23^{\circ} \mathrm{C}$. Heart rate and pulmonary artery, systemic, and left ventricular pressures were recorded continuously on a multichannel polygraph. Arterial blood was obtained $(1.5 \mathrm{~mL})$ for catecholamine measurement at 15,60,120,180,240,300, and $360 \mathrm{~min}$ after umbilical cord cutting. At these identical timed intervals, hemodynamic data and blood gas determinations were recorded. All samples were replaced with an equal volume of fresh heparinized maternal or placental blood to maintain fetal normovolemia.

Postmortem Studies. Immediately after the last blood sample and hemodynamic measurements, all 6-h animals were killed by sodium pentathol overdose. For tissue catecholamine analysis, $75-125 \mathrm{mg}$ of tissue was obtained from the right and left atrial appendage and the right and left ventricular free wall. After weighing, the tissue was placed in $1.0 \mathrm{~mL}$ ice cold $0.1 \mathrm{~N}$ perchloric acid with $5 \mathrm{mM}$ reduced glutathione and immediately homogenized using a Teflon-glass homogenizer. The homogenate was centrifuged at $2500 \mathrm{rpm}$ for $10 \mathrm{~min}$. The supernatant was removed, quick frozen on dry ice, and stored at $-70^{\circ} \mathrm{C}$ for catecholamine analysis and Lowry protein content (27). The remainder of the ventricular tissue was trimmed of residual atrial tissue, atrial-ventricular valves, and adipose and connective tissue, and weighed and processed for the BAR assay. The ventricles were washed in cold buffer and homogenized in six volumes of iced $250 \mathrm{mM}$ sucrose, $5 \mathrm{mM}$ Tris- $\mathrm{HCl}, \mathrm{pH} 7.4$, and $1 \mathrm{mM} \mathrm{MgCl}_{2}$ using a Tekmar tissuemizer (Tekmar Co., Cincinnati, $\mathrm{OH}$ ) at high speed for $60 \mathrm{~s}$. The homogenate was centrifuged at $3000 \times$ $g$ for $10 \mathrm{~min}$. The supernatant was decanted, saved, and centrifuged at $40000 \times g$ for $20 \mathrm{~min}$ at $4^{\circ} \mathrm{C}$. The resulting pellet was resuspended with the Tekmar at one-half speed and recentrifuged at $40000 \times g$ for $20 \mathrm{~min}$ at $4^{\circ} \mathrm{C}$. The final pellet was resuspended in $250 \mathrm{mM}$ sucrose, $5 \mathrm{mM}$ Tris- $\mathrm{HCl}, \mathrm{pH} 7.4$, and $1.0 \mathrm{mM} \mathrm{MgCl}_{2}$ to a final concentration of $1-2 \mathrm{mg}$ protein $/ \mathrm{mL}$ with a Teflonglass homogenizer, separated into $2.0-\mathrm{mL}$ aliquots, and quick frozen with dry ice and ethanol. Membranes were stored at $-70^{\circ} \mathrm{C}$ until assay, usually within $1 \mathrm{wk}$.

Analytical Techniques. BAR assays. Direct binding studies for BAR were performed on the partially purified membranes. Mem-

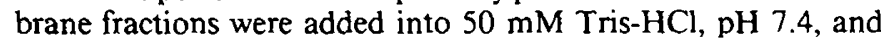
$10 \mathrm{mM} \mathrm{MgCl}$ with graded concentrations of ${ }^{3} \mathrm{H}-\mathrm{DHA}$ (sp act $50-55 \mathrm{Ci} / \mathrm{mmol}$ ) ranging from $1.0 \pm 0.3$ to $6.0 \pm 0.2 \mathrm{nM}$. Aliquots were incubated for $20 \mathrm{~min}$ at $30^{\circ} \mathrm{C}$. Bound and free material were separated by rapid filtration and washing with 20 $\mathrm{mL}$ of cold buffer on Whatman GF/C glass filters, dried, and counted in toluene liquifluor. Nonspecific binding was defined as the amount of ${ }^{3} \mathrm{H}$-DHA bound in the presence of $1.0 \mu \mathrm{M}$ D-L propranolol. Bmax and $k_{d}(n M)$ were determined by Scatchard analysis of the direct binding data and expressed as fmol ${ }^{3} \mathrm{H}$-DHA bound/mg protein. Blood samples were placed into chilled test tubes containing a final concentration of $4 \mathrm{mM}$ EGTA and $3 \mathrm{mM}$ reduced glutathione. Plasma was then separated by low-speed centrifugation at $4^{\circ} \mathrm{C}$, removed, and stored at $-70^{\circ} \mathrm{C}$ for determination of catecholamines. The catecholamines were measured by radioenzymatic assay, which has a sensitivity for norepinephrine and epinephrine of $0.10-0.20 \mathrm{nM}$ (28).

Adenyl cyclase assays. BAR stimulation of adenyl cyclase activity was determined in the partially purified myocardial membrane preparations from animals killed at birth or at $6 \mathrm{~h}$. Isoproterenol stimulation of adenyl cyclase activity was determined by slight modification of the methods of Tse et al. (29).
Before assay, the membrane preparation to be assayed was recentrifuged and resuspended in an incubation buffer that contained $50 \mathrm{mM}$ Tris- $\mathrm{HCl}, \mathrm{pH} 7.5,6 \mathrm{mM} \mathrm{MgCl}_{2}, 2 \mathrm{mM}$ DTT, and $0.2 \mathrm{mM}$ EGTA. Eighty to $120 \mu \mathrm{g}$ of the resuspended membrane preparation was incubated in the presence or absence of $10^{-5} \mathrm{M}$ GTP with $12 \mathrm{mM}$ phosphocreatine, $30 \mu \mathrm{g} /$ tube creatine phosphokinase, $1 \mathrm{mM} \mathrm{ATP}$, and isoproterenol concentrations ranging from $10^{-3}$ to $10^{-10} \mathrm{M}$. The GTP concentration chosen was based on preliminary experiments where the optimal concentration of GTP for isoproterenol stimulation of adenyl cyclase was determined to be $10^{-5} \mathrm{M}$. Total cyclase activity was determined in the presence of $6 \mathrm{mM}$ sodium fluoride. After incubation at $30^{\circ} \mathrm{C}$ for $20 \mathrm{~min}$, the tubes were immersed in ice and then boiled for $3 \mathrm{~min}$. The incubates were centrifuged at $1000 \times \mathrm{g}$ for $20 \mathrm{~min}$ to remove precipitated protein and the CAMP in the supernatant was determined by RIA using a commercially available kit from New England Nuclear-DuPont (Boston, MA). Preliminary studies were conducted to confirm that the assay as described was linear with respect to incubation time and membrane protein.

Data Analysis. The serial plasma catecholamines, heart rate, and blood pressures for the 6-h animals were compared with values just before birth by analysis of variance for repeated measures and Dunnett's test. All catecholamine values were logtransformed before statistical comparison. Data are presented as mean \pm SEM except for catecholamines, which are shown as geometric mean \pm SEM. The data for BAR and myocardial norepinephrine content were compared by unpaired $t$ test. BAR characteristics were determined by Scatchard analysis. The Scatchard data were generated by a computer program (LIGAND, 30) that determined Bmax and $k_{d}$. The dose-response curves for isoproterenol stimulation of adenyl cyclase activity were compared by a computer program (ALLFIT, 31). The ALLFIT program uses a four-parameter logistic equation to describe and compare the baseline response, peak response, $\mathrm{EC}_{50}$, and slope factor for families of dose-response curves. Both LIGAND and ALLFIT were kindly supplied by Dr. Peter J. Munson, Laboratory of Theoretical and Physical Biology, NICHHD, Bethesda, Maryland.

\section{RESULTS}

Shown in Figure 1 are the sequential catecholamine levels after delivery. There were marked increases in plasma norepinephrine and epinephrine levels. Norepinephrine before cord cutting (3.0 $\mathrm{nM}$ ) rose to a peak level of $6.6 \mathrm{nM}$ between 15 and $120 \mathrm{~min}$. Plasma norepinephrine remained elevated at 1.0-1.5 times the resting control level throughout the remainder of the study. Plasma epinephrine rose 4- to 6-fold at 15 to $120 \mathrm{~min}$ from 1.0 to $5.0 \mathrm{nM}$, respectively. The epinephrine surge was followed by sustained 2- to 3 -fold elevations over resting conditions throughout the remainder of the study.

Serial heart rate and systolic and mean blood pressure values for all ventilated animals are shown in Figure 2. There were marked increases in heart rate and blood pressure after umbilical cord cutting. Heart rate increased from 134 to 173 beats/min and systolic blood pressure from 63 to $78 \mathrm{~mm} \mathrm{Hg}$. Right ventricular thermodilution measurements of cardiac output were obtained from three of the eight animals. The earliest measurement from these animals at $60 \mathrm{~min}$ of life was $292 \mathrm{~mL} / \mathrm{kg} / \mathrm{min}$, well above the resting fetal left ventricular output of $150 \mathrm{~mL} /$ $\mathrm{kg} / \mathrm{min}$. The baseline $\mathrm{pH}, 7.37$, and $\mathrm{PaO}_{2}, 25 \mathrm{~mm} \mathrm{Hg}(3 \mathrm{kPa})$, indicated well, unstressed fetuses. The $\mathrm{pH}$ and $\mathrm{PaO}_{2}$ from the animals killed immediately at birth were comparable, 7.37 and $23 \mathrm{~mm} \mathrm{Hg} \mathrm{(} 3 \mathrm{kPa}$ ), respectively. Blood gases and $\mathrm{pH}$ were maintained in a normal physiologic range throughout the period of study.

Tissue catecholamine concentrations from time- 0 and $6-\mathrm{h}$ animals are shown in Table 1. There were no significant differences between left and right myocardial sources and these levels are presented as combined values. Over the 6-h study period, 

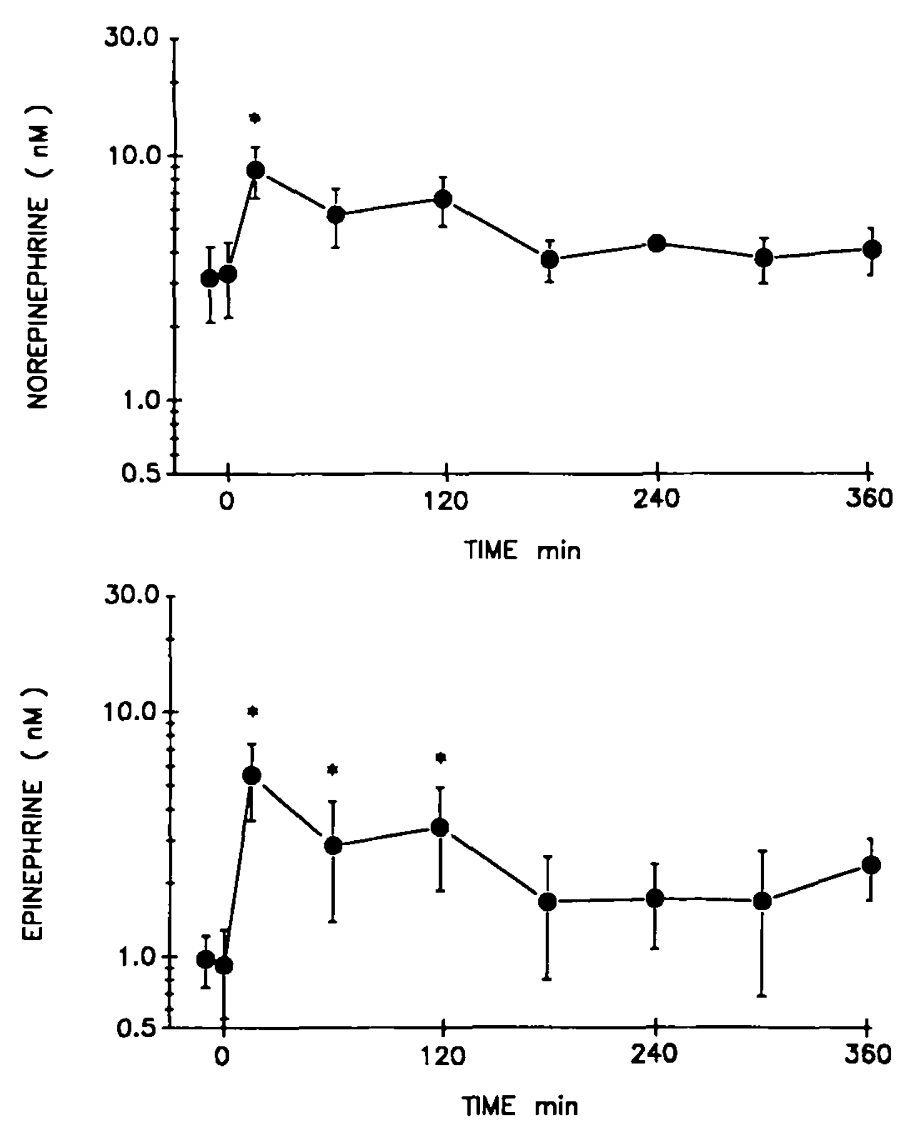

Fig. 1. Serial catecholamine levels after birth. Plasma norepinephrine and epinephrine (nM) values are shown as geometric mean \pm SEM. Asterisks indicate values significantly different from values before cord cutting. The vertical axis is logarithmic. Assays as described in Materials and Methods.

there was no significant alteration in myocardial tissue norepinephrine content. Atrial norepinephrine content was $675 \mathrm{nmol} /$ $\mathrm{mg}$ protein at time 0 and $657 \mathrm{nmol} / \mathrm{mg}$ protein at $6 \mathrm{~h}$. Ventricular norepinephrine was 775 and $769 \mathrm{nmol} / \mathrm{mg}$ protein at 0 and $6 \mathrm{~h}$, respectively.

A representative saturation binding curve and Scatchard plot are shown in Figure 3. There was no effect from elevated circulating catecholamines on newborn myocardial BAR density (Table 1). BAR density was $135 \pm 21 \mathrm{fmol} / \mathrm{mg}$ protein at time 0 and $157 \pm 19 \mathrm{fmol} / \mathrm{mg}$ protein at $6 \mathrm{~h}$. Furthermore, there was no correlation between individual values for $B \max$ and peak plasma catecholamine levels. For the time- 0 and $6-\mathrm{h}$ groups, $\mathrm{k}_{\mathrm{d}}$ were not significantly different at 4.9 and $3.4 \mathrm{nM}$, respectively.

The results of the adenyl cyclase measurements in myocardial membranes from animals killed at birth or at $6 \mathrm{~h}$ are shown in Figure 4. Isoproterenol alone, without added GTP, resulted in a small but significant stimulation of adenyl cyclase activity over basal activity (blank incubation). When GTP was added at a final concentration of $10^{-5} \mathrm{M}$, there was a $400 \%$ increase over basal adenyl cyclase activity. There was no apparent difference in either isoproterenol-stimulated activity or total adenyl cyclase activity (sodium fluoride) between animals killed at birth or after exposure to the catecholamine surge for $6 \mathrm{~h}$. To examine this question in greater detail, dose-response curves for isoproterenol stimulation of adenyl cyclase activity with or without $10^{-5} \mathrm{M}$ GTP were compared from time- 0 and 6-h animals. These results are shown in Figure 5. The results represent the mean values for assays performed in triplicate from time- 0 animals $(n=5)$ and 6-h animals $(n=5)$. There were no statistically significant differences in sensitivity $\left(\mathrm{EC}_{50}\right)$, slope factor, or maximal catecholamine-stimulated activity between the two groups. The $\mathrm{EC}_{50}$ values for the isoproterenol dose-response curves with GTP from
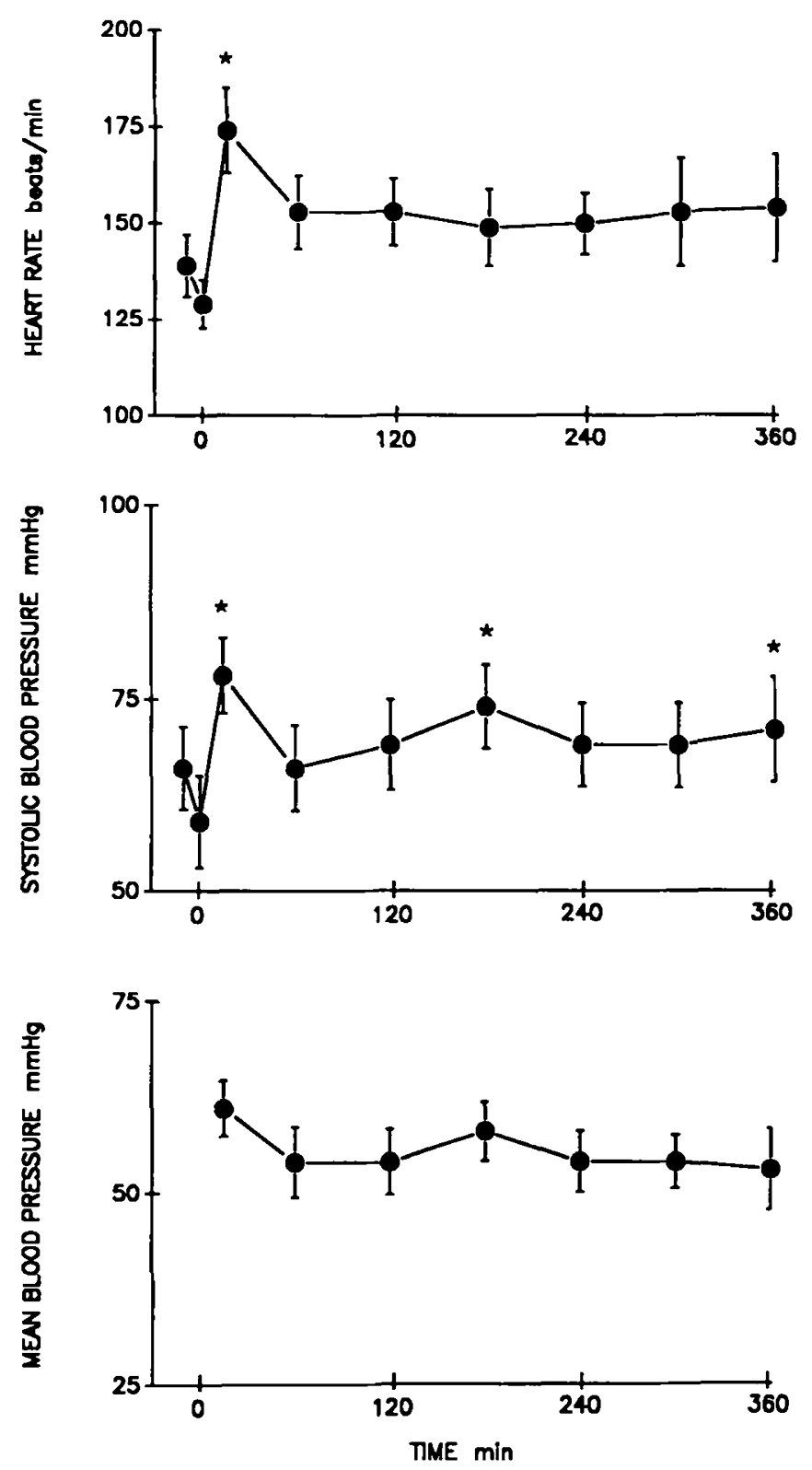

Fig. 2. Serial heart rate (bpm) and systolic and mean blood pressure $(\mathrm{mm} \mathrm{Hg})$ after birth. Values are mean \pm SEM. Asterisks indicate significantly different from values before cord cutting.

Table 1. Myocardial norepinephrine content (nmol/mg protein), $B A R$ density (fmol/mg/protein), and receptor $k_{\mathrm{d}}(\mathrm{nM})^{*}$

\begin{tabular}{lll}
\hline & \multicolumn{1}{c}{ Time 0} & \multicolumn{1}{c}{$6-\mathrm{h}$} \\
\hline Atrial NE (nmol/mg protein) & $675 \pm 231$ & $657 \pm 77$ \\
$\begin{array}{l}\text { Ventricular NE (nmol/mg protein) } \\
\text { Myocardial receptor density, Bmax }\end{array}$ & $775 \pm 272$ & $769 \pm 237$ \\
$\quad$ (fmol/mg protein) & $135 \pm 21$ & $157 \pm 19$ \\
$k_{\mathrm{o}}(\mathrm{nM})$ & $4.9 \pm 1.0$ & $3.4 \pm 0.6$ \\
\hline
\end{tabular}

* Values are mean \pm SEM. NE, norepinephrine.

the time- 0 and 6-h groups were 1.1 and $0.8510^{-6} \mathrm{M}$, respectively. This was true if the assay was performed without addition of exogenous GTP.

\section{DISCUSSION}

In our study, we measured cardiac BAR density, receptor sensitivity, circulating catecholamines, and myocardial norepinephrine content at birth and after $6 \mathrm{~h}$ of exposure to elevated 


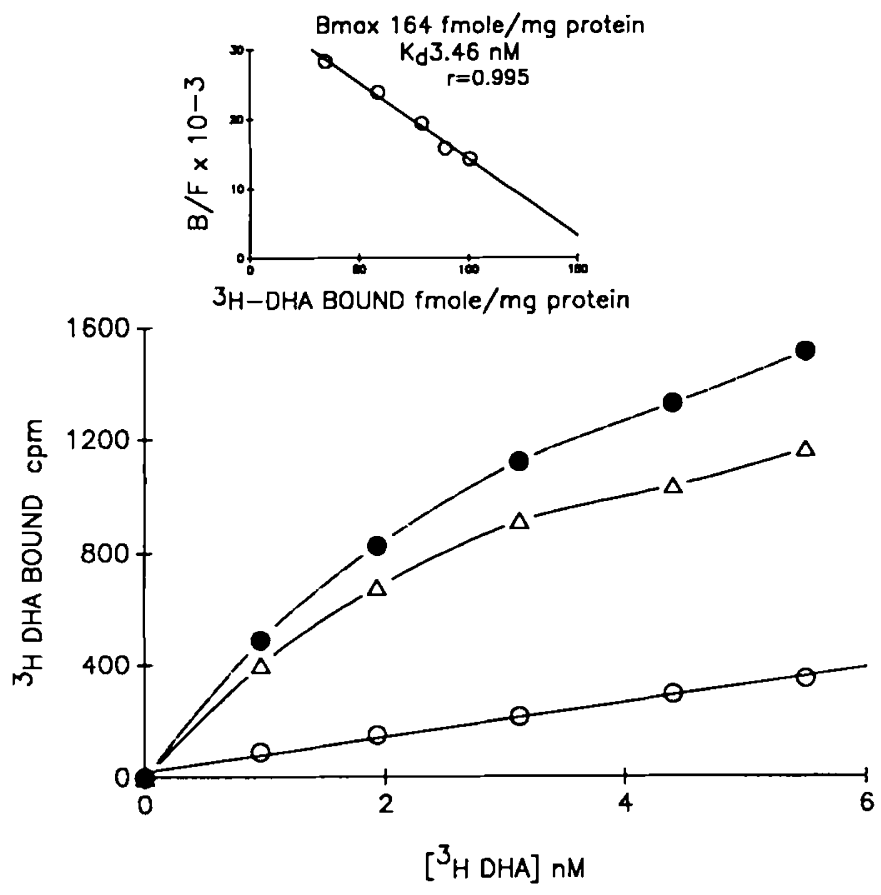

Fig. 3. A representative saturation curve and Scatchard plot (inset) for myocardial BAR binding. Total $(O)$, specific $(\Delta)$, and nonspecific $(O)$ data are shown.

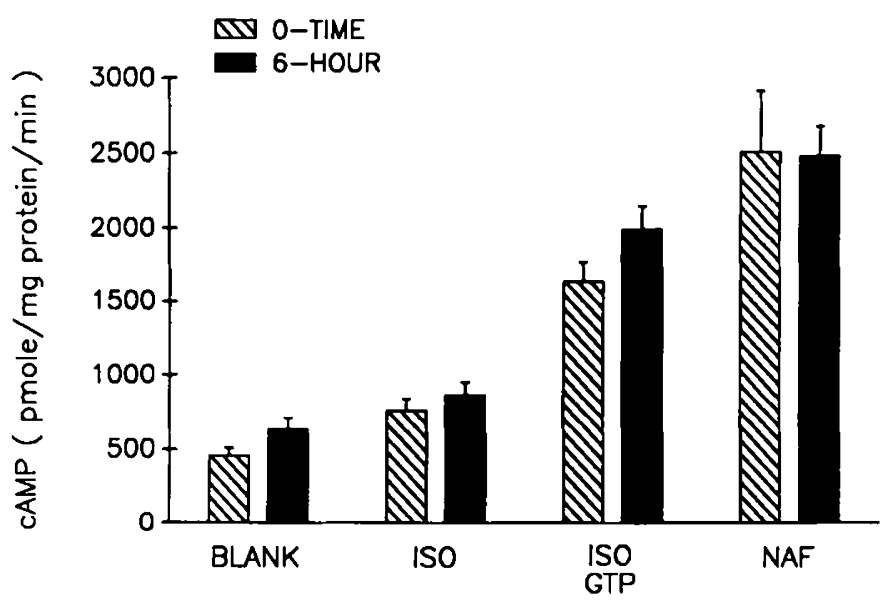

Fig. 4. Adenyl cyclase activity (cAMP produced in $\mathrm{pmol} / \mathrm{mg}$ protein/ min) in partially purified membranes from time-0 and 6-h animals. Blank values represent activity without added stimulants. Isoproterenol alone and isoproterenol plus GTP activities were determined from computer analysis of dose-response curves with isoproterenol concentrations from $10^{-3}$ to $10^{-10} \mathrm{M}$. Maximal activation of adenyl cyclase was seen at isoproterenol levels from $10^{-5}$ to $10^{-4} \mathrm{M}$. The GTP concentration was $10^{-5} \mathrm{M}$. Total cyclase activity was measured as activity in the presence of $6 \mathrm{mM}$ sodium fluoride.

plasma catecholamines. After delivery of these animals, cardiovascular performance was augmented as reflected by increased systolic and mean blood pressure, cardiac output, and heart rate. We observed a marked and sustained increase in circulating catecholamines, but no alteration in norepinephrine myocardial content, BAR density, receptor affinity, or catecholamine-stimulated adenyl cyclase activity from animals at birth or after the 6-h study period. These data indicate the absence of both homologous and heterologous receptor down-regulation over the 6-h study at this developmental age.

The purpose of the adenyl cyclase assay was to measure and compare the plasma catecholamine-induced alteration of $\beta$-receptor coupling in the time-0 and 6-h animals. This was

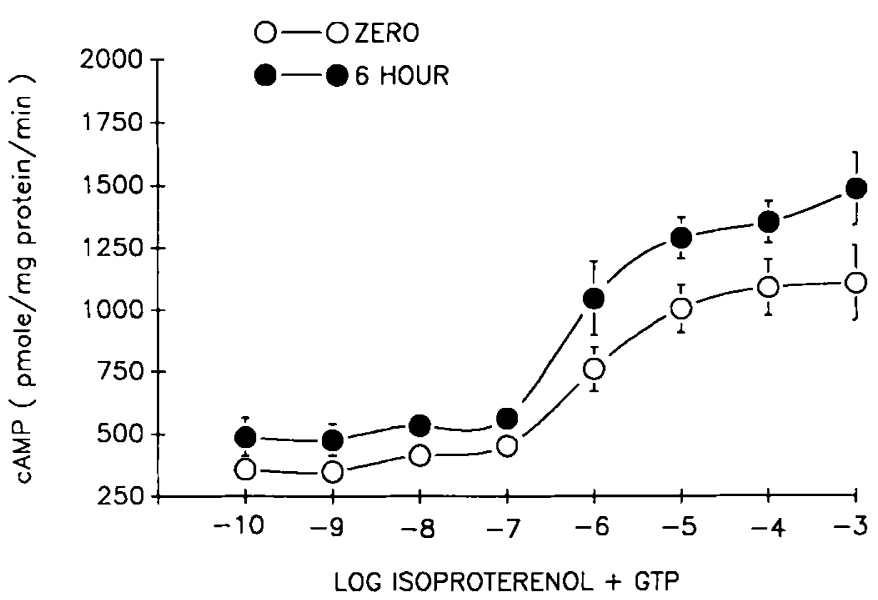

Fig. 5. Dose responses for isoproterenol stimulation of cAMP production by myocardial membranes from time- $0(n=5)$ and $6-\mathrm{h}(n=5)$ animals. All points on the dose-response curves represent net cAMP produced minus the blank. Results are mean \pm SEM for triplicate determinations. There were no differences in basal or peak activity or in $E_{\text {so }}$. Analyses and assays as described in Materials and Methods.

accomplished by measuring cAMP formation and $\mathrm{EC}_{50}$ for isoproterenol-stimulated dose responses. For both groups, isoproterenol alone or with GTP resulted in classic dose-response curves with a greater than 3-fold rise in cAMP formation and similar $\mathrm{EC}_{50}$ values of 1.1 and $0.85 \times 10^{-6} \mathrm{M}$. The similar $\mathrm{EC}_{50}$ for the two groups and a lack of influence of exogenous GTP on the $\mathrm{EC}_{50}$ for isoproterenol indicates the state of receptor coupling remained unchanged despite exposure to sustained elevation in circulating levels of endogenous catecholamines. We used fractionated tissue for our binding studies and the adenyl cyclase determinations. Membrane homogenization and manipulation in the particulate state is generally thought not to alter the behavior of heart $\beta$-receptors and membranes derived from heart tissue are considered an acceptable source of functionally active $\beta$-receptors (32). Several studies using particulate membrane preparations similar to ours report $\mathrm{EC}_{50}$ values for isoproterenol ranging from $10^{-6}$ to $10^{-7} \mathrm{M}$, which are similar to our results $(12,15,26,33-35)$.

There are a number of studies that support changes in BAR density and sensitivity after acute or chronic exposure to various adrenergic agents or endogenous catecholamines. Experiments that demonstrate rapid changes in BAR have been largely performed in vitro by incubating membrane/receptor preparations with high concentrations of agonist, usually isoproterenol at $10^{-6}$ $M(11-21)$. This level is two to three logs above the plasma concentration observed during in vivo clinical administration of this agent $(33,36)$. Furthermore, the specific use of isoproterenol may impart a greater potency for $\beta$-adrenergic stimulation compared with epinephrine or norepinephrine (37). Thus, desensitization data based upon these types of in vitro experiments may not simulate in vivo BAR responses. Rapid in vivo alterations of BAR binding sites have been demonstrated $(4,5)$. Tohmeh and Cryer (4) measured an early increase and later reduction of human leukocyte BAR binding after brief exposure to infused isoproterenol, epinephrine, or elevated endogenous plasma catecholamines. Bmax increased within $30-60 \mathrm{~min}$ of adrenergic stimulation, whereas at 4-6 h, marked loss of BAR density was demonstrated. BAR down-regulation also occurs in response to chronic in vivo adrenergic stimulation. Both elevated endogenous catecholamines and exogenous administration of selective $\beta$-agonists result in reduced leukocyte or adipocyte BAR density if exposure is prolonged for several days to weeks $(6-10)$.

A complex alteration in BAR density or sensitivity in the response to elevated plasma catecholamines has been observed in previous investigations $(33,36-40)$. These data are frequently derived from in vivo experiments in which a physiologic stress 
produces increased catecholamine secretion and adrenergic stimulation. Boreus et al. (26) measured BAR on lymphocytes and polymorphonuclear leukocytes isolated from newborn infants delivered vaginally or by cesarean section. White cells were obtained from cord blood at the time of delivery. Despite 4- to 10 -fold higher plasma catecholamines in infants delivered vaginally, neither receptor density or affinity nor isoproterenolstimulated adenyl cyclase activity were altered. In contrast, Feldman et al. (37) measured BAR density on mononuclear leukocytes after catecholamine stimulation associated with a change in posture in adult humans. They demonstrated that although receptor number remained constant, there was a significant change in isoproterenol affinity due to a reduced proportion of high-affinity binding receptors. This was associated with a significant decline in isoproterenol-stimulated cAMP production. DeBlasi et al. (36) reported no change in number or cellular distribution of BAR after in vivo exposure to either elevated endogenous catecholamines or to exogenous isoproterenol. They noted a change in isoproterenol-stimulated cAMP accumulation after postural change; however, this was not seen if exogenous GTP was provided in their assay. The estimated isoproterenol plasma concentration was 2-3 nM. In contrast, their prior in vitro data demonstrated rapid cellular redistribution of BAR after incubation with $1-10 \mu \mathrm{M}$ isoproterenol (15). These results suggest that a critical level of receptor-agonist occupancy or threshold value of adrenergic stimulation is required to effect changes in BAR binding sites. Similarly, Krall et al. (33) measured and compared human lymphocyte BAR density after in vitro exposure to graded concentrations of isoproterenol or to infused isoproterenol given to human subjects. Significant reduction of Bmax occurred only after incubation with high doses of isoproterenol $(0.01-100 \mu \mathrm{M})$. In vivo or in vitro exposure at $0.01-0.1$ $\mathrm{nM}$ did not produce alteration of BAR number.

Our study was conducted in vivo, based upon a well-described physiologic activation of the sympathoadrenal axis (22-26). Cesarean delivery resulted in peak plasma epinephrine and norepinephrine reaching approximately 9-11 nM. These levels are much higher than those observed after changes in posture, where baseline levels rise only 2 - to 3 -fold $(36,38-41)$. Plasma catecholamine levels in this study were comparable to levels observed in adults after strenuous exercise $(36,41-43)$. However, these levels are still 100- to 1000 -fold less than those used during in vitro isoproterenol studies where significant down-regulation of BAR has been observed. Our animals maintained elevated circulation catecholamines for $2 \mathrm{~h}$ followed by lower levels, which nevertheless remained 2- to 3 -fold above resting fetal concentrations. Thus, the magnitude and duration of adrenergic stimulation achieved in this in vivo model may have been insufficient to cause alteration of BAR density or affinity state.

It is unlikely that the measurement of cardiac receptor Bmax at the end of the 6-h study could have reflected a return toward control levels concurrent with stabilization of circulating plasma catecholamines. This contention is based on data supporting rapid alterations of receptor density $(4,5)$. However, after prolonged adrenergic stimulation, receptor recovery is reported to occur over several days to weeks (6-9). Furthermore, if undetected fluctuations of Bmax did occur, they were not reflected by depressed cardiovascular function or instability.

An additional factor relevant to this study is the state of cardiac sympathetic innervation as it influences transsynaptic regulation of BAR binding sites. Mature (aduit rat) myocardial receptors undergo classical regulation where chronic exposure to the $\beta$-agonist isoproterenol leads to loss of BAR binding sites accompanied by chronotropic subsensitivity (29). In contrast, the cardiac sympathetic axis of the neonatal rat is nonfunctional during the first week of life and the initial development of cardiac BAR and responsiveness to catecholamines are not transsynaptically regulated (44). The absence of altered myocardial BAR density in these newborn sheep may be due to similar developmental factors. However, sympathetic innervation of the lamb heart at birth is well developed (45) and positive inotropic and chronotropic responses do not differ from those observed in adults of many species (46-51). Furthermore, in fetal sheep lung tissue, down-regulation of Bmax has been demonstrated in response to prolonged high-dose $\beta$-agonist infusion (52).

In conclusion, we have demonstrated that despite a marked increase in circulating catecholamines at birth there is no apparent alteration in myocardial receptor density. The level and duration of adrenergic stimulation was greater than that in most short-term in vivo studies. These results suggest the absence of homologous receptor regulation, which may be influenced by developmental factors.

\section{REFERENCES}

1. Nambi P, Stadel JM, Sibley DR, Strulovici B, Caron MG, Lefkowitz RJ 1984 Mechanisms of $\beta$-adrenergic receptor desensitization. In: Lefkowitz RJ, Lindenlaub E (eds) Adrenergic Receptors: Molecular Properties and Therapeutic Implications. FK Schattauer Verlag, Stuttgart, pp 437-451

2. Lefkowitz RJ, Caron MG, Stiles GL 1984 Mechanisms of membrane-receptor regulation. N Engl J Med 310:1570-1579

3. Lefkowitz RJ, Caron MG 1985 Adrenergic receptors: molecular mechanisms of clinically relevant regulation. Clin Res 33:395-405

4. Tohmeh JF, Cryer PE 1980 Biphasic adrenergic modulation of $\beta$-adrenergic receptors in man. J Clin Invest 65:836-840.

5. Butler J, Kelly JG, O'Malley K, Pidgeon F 1983 Beta-adrenoceptor adaptation to acute exercise. J Physiol 344:113-117

6. Galant SP, Duriseti L, Underwood S, Insel PA 1978 Decreased beta-adrenergic receptors on polymorphononuclear leukocytes after adrenergic therapy. $\mathrm{N}$ Engl J Med 299:933-936

7. Aarons RD, Nies AS, Gerber JG, Molinoff PB 1983 Decreased beta adrenergic receptor density on human lymphocytes after chronic treatment with agonists. J Pharmacol Exp Ther 224:1-6

8. Fraser J, Nadeau J, Robertson D, Wood AJJ 1981 Regulation of human leukocyte beta receptors by endogenous catecholamines. J Clin Invest 67:1777-1784

9. Baumann G, Riess G, Erhardt WD, Blomer H 1981 Impaired beta-adrenergic stimulation in the uninvolved ventricle post-acute myocardial infarction. Am Heart J 101:569-581

10. Prokocimer PG, Maze M, Vickery RG, Hoffman BB 1988 Mechanism for desensitization of beta-adrenergic receptor-stimulated lipolysis in adipocytes from rats harboring pheochromocytoma. Endocrinology 123:528-533

I1. Abbracchio MP, Cattabeni F, Coen E, Torres-Hernandez Y, Omini C 1983 $\beta$-adrenoceptor desensitization in rat lung: functional and biochemical aspects. Eur J Pharmacol 89:35-42

12. Linden J, Patel A, Spanier AM, Weglicki WB 1984 Rapid agonist-induced decrease of ${ }^{125}$ I-pindolol binding to $\beta$-adrenergic receptors. J Biol Chem 259:15115-15122

13. Mukherjee C, Lefkowitz RJ 1976 Desensitization of beta-adrenergic receptors by beta-adrenergic agonists in a cell-free system: resensitization by guanosine $S^{\prime}-(\gamma, \gamma$-imino $)$ triphosphate and other purine nucleotides. Proc Natl Acad $S^{\prime}$-( $\gamma, \gamma$-imino) triphosphat
Sci USA 73:1494-1498

14. Waldo GL, Northup JK, Perkins JP, Harden TK 1983 Characterization of an altered membrane form of the beta-adrenergic receptor produced during agonist-induced desensitization. J Biol Chem 258:13900-13908

15. Motulsky HJ, Cunningham EMS, DeBlasi A, Insel PA 1986 Densitization and redistribution of $\beta$-adrenergic receptors on human mononuclear leukocytes. Am J Physiol 250:E583-E590

16. Stadel JM, Strulovici B, Nambi P, Lavin RN, Briggs MM, Caron MG, Lefkowitz RJ 1983 Desensitization of the beta-adrenergic receptor of fros erythrocytes. J Biol Chem 258:3032-3038

17. Chuang D, Costa E 1979 Evidence for internalization of the recognition site of beta-adrenergic receptor subsensitivity induced by $(-)$ isoproterenol. Proc Natl Acad Sci USA 76:3024-3028

18. Mukherjee $C$, Lefkowitz RJ 1976 Direct studies of $\beta$-adrenergic receptors in intact frog erythrocytes. Life Sci 19:1897-1906

19. Kebabian JW, Zatz M, Romero JA, Axelrod J 1975 Rapid changes in rat pineal $\beta$-adrenergic receptor: alterations in $\left.1-\int^{3} \mathrm{H}\right]$ alprenolol binding and adenylate cyclase. Proc Natl Acad Sci USA 72:3735-3739

20. Karliner JS, Simpson PC, Honbo N, Woloszyn W 1986 Mechanisms and time course of beta 1 adrenoreceptor desensitization in mammalian cardiac myocytes. Cardiovasc Res 20:221-228

21. Mahan LC, Koachman AM, Insel PA 1985 Genetic analysis of $\beta$-adrenergic receptor internalization and down regulation. Proc Natl Acad Sci USA 82:129-133

22. Lagercrantz $\mathrm{H} 1983$ The development and functional role of the sympathoadrenal system in the newborn. Intensive Care in the Newborn IV:67-75

23. Lagercrantz $H$, Bistoletti $P 1973$ Catecholamine release in the newborn infant at birth. Pediatr Res 111:889-893

24. Agata Y, Padbury JF, Ludlow JK, Polk DH, Humme JA 1986 The effect of chemical sympathectomy on catecholamine release at birth. Pediatr Res 20:1338-1344

25. Padbury J, Agata Y, Ludlow J, Ikegami M, Baylen B, Humme H 1987 Effect of fetal adrenalectomy on catecholamine release and physiologic adaptation at birth in sheep. J Clin Invest 80:1096-1103 
26. Boreus LO, Hjemdahl $P$ Lagercrantz $H$ Martinsson A, Yao AC 1986 $\beta$-adrenoreceptor function in white blood cells from newborn infants: no relation to plasma catecholamine levels. Pediatr Res 20:1152-1155

27. Lowry OH, Rosebrough NJ, Farr AL, Randall RJ 1951 Protein measuremen with folin phenol reagent. J Biol Chem 193:265-275

28. Peuler JD, Johnson GA 1977 Simultaneous single isotope radioenzymatic assay of plasma norepinephrine, epinephrine and dopamine. Life Sci 21:625636

29. Tse J, Powell JR, Baste CA, Priest RE, Kuo J 1979 Isoproterenol-induced cardiac hypertrophy: modifications in characteristics of $\beta$-adrenergic receptor, adenylate cyclase, and ventricular contraction. Endocrinology 105:246 255

30. Munson P 1983 A computerized analysis of ligand binding data. Method Enzymol 92:543-576

31. Delean A, Munson PJ, Rodbard D 1978 Simultaneous analysis of families of sigmoidal curves: application to bioassay, radioligand assay, and physiological dose-response curves. Am J Physiol 235:E97-E102

32. Kaumann AJ, Birnbaumer L 1974 Studies on receptor-mediated adenylyl cyclases. J Biol Chem 249:7874-7885

33. Krall JF, Connelly M, Tuck ML 1980 Acute regulation of beta adrenergic catecholamine sensitivity in human lymphocytes. J Pharmacol Exp 214:554 560

34. Schumacher WA, Sheppard JR, Mirkin BL 1982 Biological maturation and beta-adrenergic effectors: Pre- and postnatal development of the adenylate cyclase system in the rabbit hear. J Pharmacol Exp Ther 223:587-593

35. Limbird LE, DeLean A, Hickey A, Pike LJ, Lefkowitz RJ 1979 Differential effects of GTP on the coupling of $\beta$-adrenergic receptors to adenylate cyclase from frog and turkey erythrocytes. Biochim Biophys Acta 586:298-314

36. Deblasi A, Masiel AS, Feldman RD, Ziegler MG, Fratelli M, Dilallo M, Smith DA, Lai CC, Motulsky HJ 1986 In vivo regulation of $\beta$-adrenergic receptors on human mononuclear leukocytes: assessment of receptor number, location and function after posture change, exercise, and isoproterenol infusion. J Clin Endocrinol Metab 63:847-853

37. Feldman RD, Limbird LE, Nadea J, Fitzgerald GA, Robertson FD, Wood AJJ 1983 Dynamic regulation of leukocyte beta adrenergic receptor-agonis interactions by physiological changes in circulating catecholamines. J Clin Invest $72: 164-170$
38. Sowers JR, Connelly-Fittinghoff M, Tuck ML, Krall JF 1983 Acute changes in noradrenaline levels do not alter lymphocyte $\beta$-adrenergic receptor concentrations in man. Cardiovasc Res 184-188

39. Svartengren J, Svoboda P. Cannon B 1982 Desensitisation of $\beta$-adrenergic responsiveness in vivo. Eur J Biochem 102:203-210

40. Marsh JD, Barry WH, Neer EJ, Alexander W, Smith TW 1980 Desensitization of chick embryo ventricle to the physiological and biochemical effects of isoproterenol. Circ Res 47:493-501

41. Clutter WE, Bier DM, Shah SD. Cryer PE 1980 Epinephrine plasma metabolic clearance rates and physiologic thresholds for metabolic and hemodynamic actions in man. J Clin Invest 66:94-101

42. Silverberg AB, Shah SD, Haymond MW, Cryer PE 1978 Norepinephrine: hormone and neurotransmitter in man. Am J Physiol 234(3):E252 -E256

43. Galbo H, Holst JJ, Christensen NJ 1975 Glucagon and plasma catecholamine responses to graded and prolonged exercise in man. J Appl Physiol 38(1):7076

44. Lau C, Burke SP, Slotkin TA 1982 Maturation of sympathetic neurotransmission in the rat hean. IX. Development of transsynaptic regulation of cardiac adrenergic sensitivity. J Pharmacol Exp Ther 223:675-680

45. Lebowitz EA, Novick JS, Rudolph AM 1972 Development of myocardial sympathetic innervation in the fetal lamb. Pediatr Res 6:887-893

46. Friedman WF 1972 The intrinsic physiologic properties of the developing heart. Prog Cardiovasc Dis 15:87-110

47. Downing SE, Lee JC 1983 Analysis of cardiac adrenergic mechanisms in hypoxic lambs. Am J Physiol 244:H222-H227

48. Riemenschneider TA, Brenner RA, Mason DT 1981 Maturational changes in myocardial contractile state of newborn lambs. Pediatr Res 15:349-356

49. Minoura S, Gilber RD 1987 Postnatal change of cardiac function in lambs: effects of ganglionic block and afterload. J Devel Physiol 9:123-135

50. Assali NS, Brinkman CR, Woods JR, Dandavino A, Nuwayhid B 1977 Development of neurohumoral control of fetal, neonatal, and adult cardiovascular functions. Am J Obstet Gynecol 129:748-759

51. Kirkpatrick SE, Pitlick PT, Naliboff J, Friedman WF 1976 Frank-Starling relationship as an important determinant of fetal cardiac output. Am J Physiol 23I(2):495-500

52. Warburton D, Parton L. Buckley S, Cosico L. Saluna T 1987 Effects of beta-2 agonist on metabolic regulation in the fetal lamb lung. J Pharmacol Exp Ther 242:389-393 